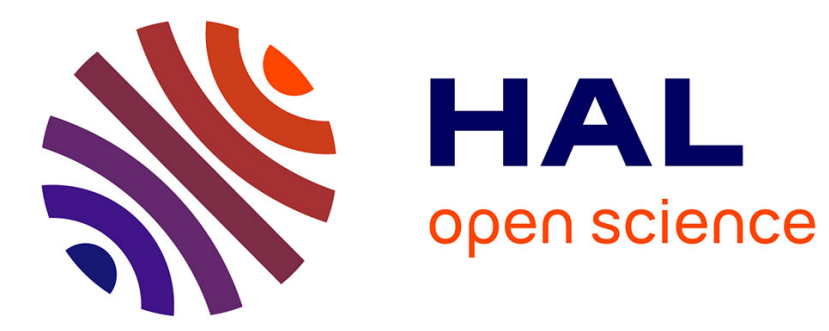

\title{
Nickel foam as a new material for chlortetracycline electrochemical oxidation Biodegradability improvement and biological treatment
}

M. Saidi, Florence Fourcade, Nizar Bellakhal, A. Amrane, Florence Geneste

\section{To cite this version:}

M. Saidi, Florence Fourcade, Nizar Bellakhal, A. Amrane, Florence Geneste. Nickel foam as a new material for chlortetracycline electrochemical oxidation Biodegradability improvement and biological treatment. Journal of Electroanalytical Chemistry, 2020, 878, pp.114543. 10.1016/j.jelechem.2020.114543 . hal-02932012

\section{HAL Id: hal-02932012 \\ https://hal.science/hal-02932012}

Submitted on 12 Nov 2020

HAL is a multi-disciplinary open access archive for the deposit and dissemination of scientific research documents, whether they are published or not. The documents may come from teaching and research institutions in France or abroad, or from public or private research centers.
L'archive ouverte pluridisciplinaire HAL, est destinée au dépôt et à la diffusion de documents scientifiques de niveau recherche, publiés ou non, émanant des établissements d'enseignement et de recherche français ou étrangers, des laboratoires publics ou privés. 
Nickel foam as a new material for chlortetracycline electrochemical oxidation: biodegradability improvement and biological treatment

Malek Saidi ${ }^{a, b, c,}$, Florence Fourcade ${ }^{b,}{ }^{*}$, Nizar Bellakhal ${ }^{a}$, Abdeltif Amrane ${ }^{b}$, Florence Geneste ${ }^{c,}$

a) Unité de recherche de Catalyse, Electrochimie, Nanomateriaux et leurs Applications et Didactique (CENAD), Institut National des Sciences Appliquées et de Technologie (INSAT), Université de Carthage 1080 Tunis, Tunisie.

b) Univ Rennes, Ecole Nationale Supérieure de Chimie de Rennes, CNRS, ISCR - UMR6226, F-35000 rennes, France

c) Univ Rennes, CNRS, ISCR-UMR 6226, F-35000 Rennes, France

\section{Abstract}

Chlortetracycline CTC is an organochlorine compound released from industrial pharmaceutical was te. This pollutant had dangerous effects in aquatic organisms and human health, since it is responsible for inhibition of microbial activity and growth. In this study, the elimination of CTC from water is 
targeted. Biodegradability, based on the $\mathrm{BOD}_{5}$ / $\mathrm{COD}$ ratio was studied, showing the non-feasibility of a direct biological treatment. Cyclic voltammetry analysis on a nickel electrode revealed a significant electrochemical activity of CTC. An electrochemical pre-treatment was therefore carried out in a percolation cell using a nickel foam as a working electrode at the potential of $0.5 \mathrm{~V} / \mathrm{SCE}$. The operating parameters were optimized. A degradation yield of $99 \%$ was achieved for an initial concentration of pollutant of $50 \mathrm{mg} \mathrm{L}^{-1}$ and a flow rate of $5 \mathrm{~mL} \mathrm{~min}{ }^{-1}$ in alkaline conditions. After electrolysis, a total dechlorination of CTC was observed. The biodegradability ratio was improved, from 0.13 to 0.33 after electrolysis; while the dissolved organic carbon (DOC) analysis revealed that the level of mineralization remained low $27 \%$. A 21 days biological treatment with activated sludge was then carried out, leading to an overall mineralization yield of $78 \%$.

Keywords:

Chlortetracycline, electrochemical oxidation, dechlorination, biodegradability, coupling process

\section{Introduction}

The low cost and good oral absorption of tetracycline (TC) derivatives make it the most used antimicrobial in veterinary medicine and agriculture with $14 \%$ of the total antibiotic usage in medicine and animal husbandry [1, 2]. Chlortetracycline CTC (Fig. 1) is the most heavily consumed owing to its low price, broad antibiotic effect, and potential for promoting the growth of livestock [3]. Therefore, CTC has the most negative impact on the environment of all tetracycline derivatives [4]. Furthermore, this chlorinated tetracycline is a persistent compound that can be found at a relatively 
high concentration in nature [5]. Its toxicity is hundreds of times higher than that of other veterinary antibiotics such as sulfamethazine [6].<smiles>CN(C)[C@H]1C(O)=C(C(N)=O)C(=O)[C@]2(O)C(O)=C3C(=O)c4c(O)ccc(Cl)c4C(O)(O)[C@@]3(C)C[C@H]12</smiles>

Fig. 1. Chemical structure of the chlortetracycline molecule

Although pharmaceutical residues are only the subject of a watch list, the very low biodegradability of CTC makes it viewed as a significant environmental pollutant [7, 8]. Chlortetracycline has been detected in different aquatic environments, such as surface water (122.3 $\left.\mathrm{ng} \mathrm{L}^{-1}\right)$ and ground water (86.6 ng L-1) [9]. These high levels of CTC have bad effects on ecological system and human health since it is responsible for inhibition of microbial activity and growth [10], phytoplankton toxicity [11], and inhibition of protein synthesis [12]. CTC removal from water becomes then an urgent issue.

Biodegradation cannot be an effective remediation process to remove CTC from water, since the presence of chlorine atoms on the phenyl ring is a factor that favours the toxicity of aryl compounds $[13,14]$. In that case, a pre-treatment method is necessary to increase CTC biodegradability prior to a biological treatment.

Chemical and physicochemical techniques have been widely studied in order to remove tetracycline from water. Adsorption is one of the most effective and low cost methods. In Ahmad et al. study [15], commercial and modified activated carbons have been implemented showing good removal efficiency. Biochar, product of biomass pyrolysis, is also an efficient material for CTC adsorption; especially when it is coupled with flocculation process $[16,17]$. However, supplementary degradation processes are needed for the elimination of biorecalcitrant pollutants. Advanced oxidation processes (AOPs) such as electro-Fenton, electrooxidation, ozonation and photo-catalysis have been applied in order to enhance CTC removal efficiency $[18,19,20,21,22]$. These processes are based on the generation of hydroxyl radicals $\left({ }^{\circ} \mathrm{OH}\right)$, known for their high oxidation capacity but also non-selectivity for organic pollutants [23]. Moreover, combined processes involving photocatalysis coupled to a biological treatment have been considered for TC removal, showing good degradation yields and biodegradableby-products [24].

Electrochemical oxidation of biorecalcitrant compounds has also been reported as a pre-treatment to improve their biodegradability prior to a biological treatment [25]. Thus, previous studies dealing with direct electrooxidation of tetracycline have been carried out in a homemade percolation flowcell involving a graphite felt electrode [26]. Results showed an almost total TC removal, and biodegradability has been improved for a final $\mathrm{BOD}_{5} / \mathrm{COD}$ of 0.39 . Graphite felt electrodes modified by nickel electro-deposition have been also used for TC pre-treatment leading to the same conversion yield 99\%. Mineralization yields remained low, but biodegradability has been well improved for a $\mathrm{BOD}_{5} / \mathrm{COD}$ ratio increasing from 0 to 0.45 . After a biological treatment, the overall mineralization yield reached $69 \%$ [27]. 
Three-dimensional porous electrodes are very commonly used in electrochemical treatment of persistent organic pollutants, since they show high specific surface area [28]. The metallic foams are undoubtedly very interesting as porous electrode for their catalytic properties [29]. Thus, Nickel based materials have been intensively investigated and considered as good potential electrode materials due to their high chemical and thermal stability, ready availability, environmentally benign nature and relatively low cost [30]. In addition to the properties of the bulk material, nickel foam has a desirable three-dimensional network structure with large specific surface area and good electrical conductivity [31].

The encouraging results previously obtained with TC [26], led us to study electrooxidation on nickel to degrade the most toxic tetracydine derivative, CTC. This coupled process combining an electrochemical oxidation pretreatment with a biological process for CTC treatment is reported for the first time in this work. It was interesting to look into the chlorine atom conversion during the treatment to check that toxic chlorinated by-products were not formed. CTC electroactivity was first investigated by cyclic voltammetry analysis on nickel electrode. Its electrochemical oxidation was carried out in a percolation cell involving nickel foam as a working electrode, in view of biodegradability improvement. The biodegradability of the electrolyzed solution was then evaluated by a biological treatment.

\section{Materials and methods}

\subsection{Chemicals}

7-chlortetracycline hydrochloride ( $\geq 75 \%$ HPLC-grade) was purchased from Sigma Aldrich (SaintQuentin Fallavier, France). Acetonitrile was HPLC grade from Fisher Scientific (IIlkirch, France), and formic acid (LC-MS grade, 98\%) was purchased from J.T. Baker (Deventer, Holland). All standards were prepared with ultra-pure water (Purelab Options- Q7/15, Elga, $18.2 \mathrm{MU} \mathrm{cm}^{-1}$ ). All other reagents were of analytical grade. The nickel foam was purchased from Lizhiyuan Battery Sales Department, China (Ni purity: $99.9 \%$, density: $320 \pm 20 \mathrm{~g} / \mathrm{m}^{3}$, thickness: $1 \mathrm{~mm}$, diameter: $4 \mathrm{~cm}$ )

\subsection{Analysis}

\subsubsection{Cyclic voltammetryanalysis}

The electrochemical behaviour of chlortetracycline was studied by cydic voltammetry analysis. Nickel electrode $\left(20 \mathrm{~mm}^{2}\right)$ was used as a working electrode in a conventional three electrode-cell with a platinum wire as counter electrode. The reference electrode was a saturated calomel electrode located near the working electrode. The electrochemical behaviour of a $20 \mathrm{~mL}$ CTC solution was examined in alkaline ( $\left.\mathrm{NaOH} 0.1 \mathrm{~mol} \mathrm{~L}^{-1}\right)$, acidic $\left(\mathrm{H}_{2} \mathrm{SO}_{4} 0.5 \mathrm{~mol} \mathrm{~L}^{-1}\right)$ and neutral $\left(\mathrm{Na}_{2} \mathrm{SO}_{4} 0.1 \mathrm{~mol} \mathrm{L^{1 }}\right)$ media at ambient temperature under nitrogen atmosphere. Voltammograms were obtained by cyclic voltammetry $\left(100 \mathrm{mV} \mathrm{s}^{-1}\right)$ using an e-daq potenstiostat linked to an e-corder 401 converter. 


\subsubsection{UPLC}

The residual chlortetracycline concentration was determined by a UPLC (ultra-high-pressure liquid chromatography) system involving a Waters Acquity UPLC ${ }^{\circledR} \mathrm{H}$-Class gradient pump and a PDA (photo diode array) UV detector. The $\lambda_{\max }$ was $273 \mathrm{~nm}$ for CTC. A C18 BEH (bridged ethylene hybrid) column, $1.7 \mathrm{~mm}(2.1 \times 50 \mathrm{~mm})$ was used. A gradient elution was carried out with $0.1 \%$ formic acid in ultra pure water (solvent A) and acetonitrile (solvent B) as follows: 90/10\% from 0 to $1 \mathrm{~min}$; from 1 to 8 min elution was linearly modified from $90 / 10$ to $0 / 100 \%$, maintained at $0 / 100 \%$ from 8 to 8.5 min; from 8.5 to 9 min elution was linearly modified from $0 / 100$ to $90 / 10 \%$, where it was maintained from 9 to 10 min for solvents $A$ and B, respectively. CTC signal was detected at 3.5 min retention time.

\subsubsection{Ion-exchange chromatography (IC)}

A DIONEX DX120 ion chromatography, equipped with a conductivity detector, was used to identify the generated inorganic ions $\left(\mathrm{Cl}^{-}\right.$and $\left.\mathrm{NO}_{3}{ }^{-}\right)$. The stationary phase was a DIONEX AS19 $(4 \times 250 \mathrm{~mm})$ ion-exclusion column. The sample was eluted with potassium hydroxide at a flow rate of $1 \mathrm{~mL} \mathrm{~min}$. The detection was carried out by conductivity with a self-regenerating suppressor (SRS).

\subsubsection{Dissolved Organic Carbon (DOC) and Totalnitrogen measurements}

Dissolved organic carbon and total nitrogen were measured by means of a Schimadzu total organic analyzer (TOC- $\mathrm{V}_{\mathrm{CPH}}$ TOC- $\left.\mathrm{V}_{\mathrm{CPN}} / \mathrm{TOC}-\mathrm{V}_{\mathrm{WP}}\right) . \mathrm{HCl}(2 \mathrm{~N})$ and $\mathrm{H}_{3} \mathrm{PO}_{4}(25 \%)$ were considered for $\mathrm{CO}_{2}$ and $\mathrm{NO}$ production. Organic carbon compounds were combusted and converted to $\mathrm{CO}_{2}$, which was detected by a non-dispersive infrared detector (NDIR). Dissolved nitrogen compounds were combusted and converted to NO, which was then mixed with ozone chemiluminescence for detection by a photomultiplier. Analyses were run in duplicate.

\subsubsection{Chemicaloxygen demand (COD) measurements}

Chemical oxygen demand (COD) was measured by means of a Test Nanocolor ${ }^{\circledast}$ CSB 160 from Macherey-Nagel (Düren, Germany). The amount of oxygen required for the oxidation of the organic and mineral matter at $148^{\circ} \mathrm{C}$ for $2 \mathrm{~h}$ was quantified after oxidation with $\mathrm{K}_{2} \mathrm{Cr}_{2} \mathrm{O}_{7}$ at acidic $\mathrm{pH}$ and with heating. Analyses were duplicated.

\subsubsection{Biochemical oxygen demand $\left(B O D_{5}\right)$ measurements}

$\mathrm{BOD}_{5}$ measurements was carried out in an Oxitop IS6 (WTW, Ales, France), in order to evaluate biodegradability. Activated sludge was provided by a local wastewater treatment plant (Rennes Beaurade, Bretagne, France). The flasks were inoculated by activated sludge initially concentrated at $0.05 \mathrm{~g} \mathrm{~L}^{-1}$. The total volume of sample was deduced from the expected $\mathrm{BOD}_{5}$ range, which was calculated from the equation $\mathrm{BOD}_{5}=\mathrm{COD} / 1.46$ [32]. The composition of the mineral solution was (in $\mathrm{g}$ $\mathrm{L}^{-1}$ ): $\mathrm{MgSO}_{4} .7 \mathrm{H}_{2} \mathrm{O}, 22.5 ; \mathrm{CaCl}_{2}, 27.5 ; \mathrm{FeCl}_{3}, 0.15 ; \mathrm{NH}_{4} \mathrm{Cl}, 2.0$; and that of the phosphate solution was ( $\mathrm{g}$ $\mathrm{L}^{-1}$ ): $\mathrm{Na}_{2} \mathrm{HPO}_{4}, 6.80 ; \mathrm{KH}_{2} \mathrm{PO}_{4}, 2.80$. Regarding the blank solution, a similar protocol was considered except for the sample, it was replaced by water to deduce the biological oxygen demand corresponding to the endogenous respiration. The control flask was prepared in the same way, but 
this time the sample was replaced by a solution of easily biodegradable compounds, namely glutamic acid $\left(150 \mathrm{mg} \mathrm{L}^{-1}\right)$ and glucose $\left(150 \mathrm{mg} \mathrm{L}^{-1}\right)$. Before use, $\mathrm{KOH}$ was added to achieve neutral $\mathrm{pH}(7.0 \pm$ 0.2). All $\mathrm{BOD}_{5}$ measurements were duplicated.

\subsection{Experimentalprocedures}

\subsubsection{Electrochemical pre-treatment}

A home-made flow cell was used for the electrochemical pre-treatment. As shown in Fig. 2, the continuous percolation system was composed from two cationic exchange membranes (lonac 3470 Lanxess SAS, Courbevoie, France) separating the working electrode from two interconnected stainless steel counter electrode compartments. The working electrode was composed of three juxtaposed nickel foams ( $0.3 \mathrm{~cm}$ thickness and $4 \mathrm{~cm}$ diameter), corresponding to a volume of 3.77 $\mathrm{cm}^{3}$. SEM image obtained by SEM JEOL 6301F ( $9 \mathrm{kV}$ ) microscope, showed a smooth surface of the nickel foam (Fig. 3). The working electrode was located between two counter-electrodes in order to provide a good homogeneity of the potential distribution [33]. The reference electrode (SCE) was positioned in the middle of the foam. The potential control was performed using an e-daq potentiostat linked to an e-corder 401 converter (AD Instruments Pty Ltd., Castle Hill, Australia). 0.1 mol L $\mathrm{L}^{-1} \mathrm{NaOH}$ was used as supporting electrolyte. The chlortetracycline solution $\left(50 \mathrm{mg} \mathrm{L}^{-1}\right)$ percolated the three-dimensional electrode at a constant flow rate monitored by a Gilson minipuls 2 peristaltic pump (Middleton, WI, USA). 
Fig. 2. Schematic diagram of the percolation cell: 1 . cationic membranes; 2 . saturat ed calomel electrode (SCE); 3 . Working electrode (disc of nickel foam: $4 \mathrm{~cm}$ diameter, $0.3 \mathrm{~cm}$ thickness); 4 . Auxiliary counter electrodes,

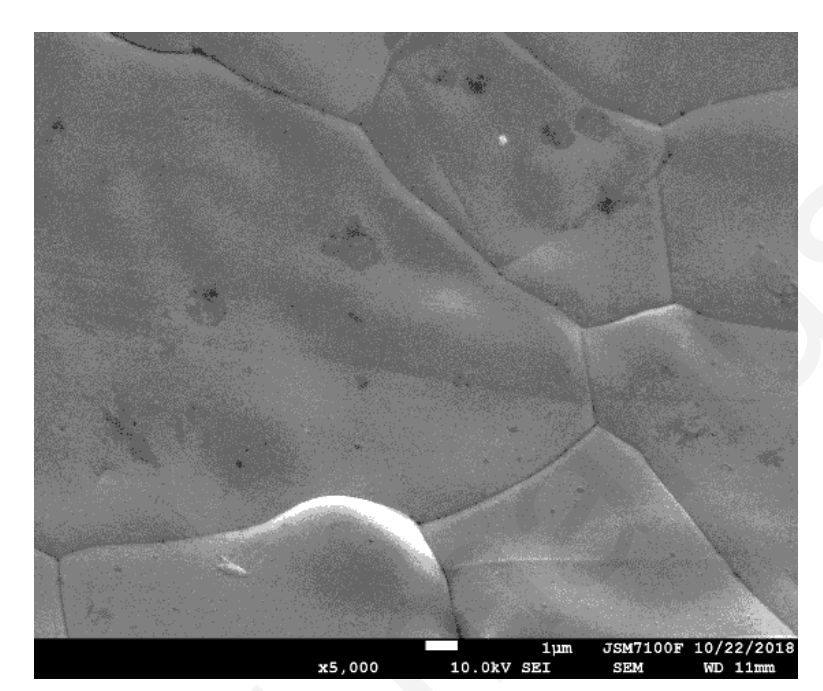

Fig. 3. SEM image of a nickel foam (thickness $0.3 \mathrm{~cm}$ )

\subsubsection{Biological treatment}

Cultures were performed in duplicate for 21 days at $25^{\circ} \mathrm{C}$ in $500 \mathrm{~mL}$ Erlenmeyer flasks, closed with a cellulose cap to guarantee oxygenation and loaded with $200 \mathrm{~mL}$ of magnetically stirred ( $200 \mathrm{rpm}$ ) non-treated chlortetracycline or chlortetracycline solutions electrolyzed for 5 hours. An initial 
activated sludge concentration of $0.5 \mathrm{~g} \mathrm{~L}^{-1}$ was inoculated and the following minerals were used for all experiments (mg L-1): $\mathrm{K}_{2} \mathrm{HPO}_{4}, 208 ; \mathrm{KH}_{2} \mathrm{PO}_{4}, 85 ; \mathrm{Na}_{2} \mathrm{HPO}_{4} .2 \mathrm{H}_{2} \mathrm{O}, 154.4 ; \mathrm{MgSO}_{4} .7 \mathrm{H} 2 \mathrm{O}, 22.6 ; \mathrm{CaCl}_{2}$, 27.6; $\mathrm{FeCl}_{3} .6 \mathrm{H} 2 \mathrm{O}, 0.26 ; \mathrm{NH}_{4} \mathrm{Cl}, 75$ [34]. The $\mathrm{pH}$ was then fixed to 7.0 with $\mathrm{NaOH}$ solution $\left(2 \mathrm{mmol} \mathrm{L}^{-1}\right)$. Samples were taken regularly for DOC measurements and filtered on $0.45 \mu \mathrm{m}$ Chromafil ${ }^{\circledR}$ Xtra PET $45 / 25$.

\section{Results and discussion}

\subsection{Electroactivity of CTC on Nickel Foam electrode}

Fig. 4. Cyclic voltammogram of $1 \mathrm{~g} \mathrm{~L}^{-1} \mathrm{CTC}$ in $0.1 \mathrm{~mol} \mathrm{~L}^{-1} \mathrm{NaOH}$ on a nickel electrode $\left(\mathrm{S}=20 \mathrm{~mm}^{2}\right)$, under nitrogen a tmos phere and $\mathrm{T}=298 \mathrm{~K}$. Current-potential curves in the absence (red) and in the presence of CTC (black line). (100 mV s$\left.{ }^{-1}\right)$

The electrochemical behaviour of CTC on nickel electrode was studied in basic $\left(0.1 \mathrm{~mol} \mathrm{~L}^{-1} \mathrm{NaOH}\right)$ medium by cyclic voltammetry. According to Fig. 4, voltammograms displayed a quasi-reversible system at $0.4 \mathrm{~V} / \mathrm{SCE}(0.64 \mathrm{~V} / \mathrm{SHE}$ at $\mathrm{pH} 13)$ for $0.1 \mathrm{~mol} \mathrm{~L}^{-1} \mathrm{NaOH}$ solution, which is in agreement with the study of Belkheiri et al. [27]. Since the $\mathrm{pH}$ was above 12, this signal can be related to the reversible couple nickel hydroxide/nickel oxyhydroxide $\left(\mathrm{Ni}(\mathrm{OH})_{2} / \mathrm{NiOOH}\right)$.

$$
\mathrm{Ni}(\mathrm{OH})_{2} \mathrm{NiOOH}+\mathrm{H}^{+}+\mathrm{e}^{-}
$$

In presence of CTC, an increase of the anodic peak was observed for the quasi-reversible system in alkaline medium. This increase showed the electrocatalytic effect of the nickel electrode on the oxidation of the target molecule. In alkaline medium, $\mathrm{NiOOH}$ groups were probably responsible for the CTC oxidation. It can be therefore concluded that in alkaline medium, an electrochemical oxidation on nickel foam electrode can be an efficient method for chlortetracycline pre-treatment.

\subsection{Electrochemical pre-treatment of CTC}

\subsubsection{Effect of the oxidation potential}

$50 \mathrm{mg} \mathrm{L}^{-1}$ of CTC solution was treated in a homemade flow cell using a nickel foam electrode in alkaline medium ( $\mathrm{pH}$ 12). The electrolysis was carried out for $5 \mathrm{~h}$ with a constant flow rate of $5 \mathrm{~mL}$ $\mathrm{min}^{-1}$ at different potential values, chosen in the potential range corresponding to the formation of the $\mathrm{NiOOH}$ groups (Fig. 4). The studied values were chosen based on the voltammogram of Fig. 4, showing a significant electrochemical activity of chlortetracydine in oxidation at $0.5 \mathrm{~V} / \mathrm{SCE}$. As expected, a negligible CTC degradation was observed (Fig. 5) when the electrolysis was performed at $0.3 \mathrm{~V} / \mathrm{SCE}$. More than $99 \%$ of CTC degradation was achieved at a potential of $0.5 \mathrm{~V} / \mathrm{SCE}$. However, when the potential reached $0.7 \mathrm{~V} / \mathrm{SCE}$, the oxidation of the target molecule decreased to $5 \%$, showing a high competition with the oxidation of water. Indeed, $\mathrm{pH}$ measurement after electrolysis showed a pH decrease from 12 (before electrolysis) to 8 . Therefore, $\mathrm{NiOOH}$ can no more be formed (Eq. 1), inhibiting the catalytic effect of nickel electrode on CTC oxidation. 
Fig. 5. Effect of the electrolysis potential on the degradation (\%[CTC] removal) of CTC by the oxidative pre -treatment on a nickel foam electrode for $300 \mathrm{~min}$ of electrolysis at $5 \mathrm{~mL} \mathrm{~min}^{-1}$ and $[\mathrm{CTC}]_{0}=50 \mathrm{mg} \mathrm{L}^{-1}$. Error bars are based on duplicate measurements.

\subsubsection{Effect of the initial CTC concentration}

3.2.2.1. Degradation and mineralization efficiency

Fig. 6. Effect of the initial CTC concentration on the degradation (a), and mineralization (b) for 300 min of electrolysis at $0.5 \mathrm{~V} / \mathrm{SCE}$ and $5 \mathrm{~mL}$ $\mathrm{min}^{-1}$. Error bars are based on duplicate measurements.

It is relevant to investigate the CTC degradation during the oxidation pre-treatment under different initial concentrations, in order to gain a better characterization of the oxidative power of the process. Anodic oxidation was performed in $\mathrm{NaOH}$ alkaline medium $(\mathrm{pH} 12)$ at $0.5 \mathrm{~V} / \mathrm{SCE}$ for $5 \mathrm{~h}$. The flow rate was set to $5 \mathrm{~mL} \mathrm{~min}{ }^{-1}$. After $180 \mathrm{~min}$ of electrolysis, the oxidation yield exceeded $99 \%$ for $50 \mathrm{mg} \mathrm{L}^{-1}$ initial CTC concentration. A higher concentration of CTC $\left(100 \mathrm{mg} \mathrm{L}^{-1}\right)$ required a longer electrolysis time, since the degradation of chlortetracycline was only $42 \%$ after $180 \mathrm{~min}$ of electrolysis. After that, CTC concentration remained constant till the end of electrolysis. Similarly to the impact of the potential (cf. 2.1), pH value decreased significantly after electrolysis; from 12 (before electrolysis) to 8 that prevents $\mathrm{NiOOH}$ formation and then the CTC catalytic oxidation. As displayed in Fig. 6b, CTC mineralized slowly. Indeed, a significant DOC decrease was only detected after $3 \mathrm{~h}$ and the mineralization levels remained low even at the end of the runs; only $9 \%$ of the organic carbon was removed for a $100 \mathrm{mg} \mathrm{L}^{-1}$ initial CTC solution, while $27 \%$ of DOC removal was reached for a CTC 
concentration of $50 \mathrm{mg} \mathrm{L}^{-1}$. To achieve a high mineralization rate, which reduces the environmental risks of effluent discharges [35], subsequent biological treatment seemed therefore relevant, owing to the significant residual organic carbon content. Indeed, organic CTC transformation products can be used as a carbon source by biomass [36].

\subsubsection{CTC biodegradability study}

Fig. 7. Effect of the $\mathrm{CTC}$ initial concentration on $\mathrm{BOD}_{5} / \mathrm{COD}$ ratio (a) after 5 hours of the oxidative pre-treatment (b) \%CTC removal, \%DOC removal and \%COD removal (b). Error bars are based on duplicate measurements.

The electrochemical pre-treatment was performed in order to improve the CTC biodegradability. Aerobic biodegradability study was carried out to assess the relevance of a subsequent biological treatment with activated sludge. Therefore, $\mathrm{BOD}_{5}$ was measured before and after electrolysis.

As expected, the untreated chlortetracycline was non-biodegradable for both 50 and $100 \mathrm{mg} \mathrm{L}^{-1}$ initial concentrations with $\mathrm{BOD}_{5} / \mathrm{COD}$ ratios equal to 0.13 and 0.07 , respectively. It is important to note that the considered concentrations had an effect on the target molecule biodegradability. It was in agreement with previous findings showing that tetracycline is biodegradable up to $18 \mathrm{mg} \mathrm{L}^{-1}$ initial concentration [24]; while, beyond this value TC inhibited the bacterial growth. After electrolysis, the $\mathrm{BOD}_{5} / \mathrm{COD}$ ratio increased and reached 0.33 for the oxidized $50 \mathrm{mg} \mathrm{L}^{-1} \mathrm{CTC}$ solution. This value was close to the limit of biodegradability (0.4) usually admitted [37, 38], showing that a biological treatment with activated sludge can be envisaged. According to Fig. 7a, by doubling the initial CTC concentration, the electrolyzed solution remained very difficult to biodegrade, according to the low $\mathrm{BOD}_{5} / \mathrm{COD}$ ratio, 0.16 . Consequently, a biological treatment seemed not relevant because the microorganisms were unable to assimilate the by-products generated during the electrolysis of CTC and CTC in a still high concentration. Furthermore, COD removal yields decreased from $19.7 \%$ to 
11.2\% when increasing the initial CTC amount from 50 to $100 \mathrm{mg} \mathrm{L}^{-1}$ (Fig.7b). Consequently, chemical oxidation appeared more effective for lower initial CTC concentration. Thus, the oxidative pretreatment seemed more suitable for a $50 \mathrm{mg} \mathrm{L}^{-1} \mathrm{CTC}$ concentration in the experimental conditions used in this work.

\subsubsection{Effect of the flow rate}

Fig. 8. Effect of the flow rate on the CTC removal for $300 \mathrm{~min}$ of electrolysis at $0.5 \mathrm{~V} / \mathrm{SCE}$ and $[\mathrm{CTC}]_{0}=50 \mathrm{mg} \mathrm{L}^{-1}$. Error bars are based on duplicate measurements.

The flow rate is an influential parameter in the flow electrochemical cell. CTC oxidation was first studied for $5 \mathrm{~mL} \mathrm{~min}{ }^{-1}$. The target molecule was totally removed after $100 \mathrm{~min}$ of electrolysis. Electrolysis was also examined at a lower flow rate in order to see if the kinetics of the oxidation reaction can be improved. According to Fig. 8, the oxidation rate decreased and only $76 \%$ of elimination was achieved after $100 \mathrm{~min}$ of electrolysis at $3 \mathrm{~mL} \mathrm{~min}{ }^{-1}$. When the flow rate was higher, the mass transport of compounds to the electrode surface probably increased, leading to a more effective CTC oxidation. After 100 min of electrolysis, a pH decrease (7.6) appeared to be responsible for the plateau displayed in Fig. 8 for 3 and $5 \mathrm{~mL} \mathrm{~min}^{-1}$ flow rates. Thus, the formation of $\mathrm{NiOOH}$ groups at the electrode surface was inhibited and the oxidation of water became favored. The oxidation reaction was consequently stopped for 3 and $5 \mathrm{~mL} \mathrm{~min}{ }^{-1}$ flow rates. These results showed that the reaction was not limited by the kinetics of the reaction occurring at the surface of the nickel foam. Interestingly, even if $24 \%$ of CTC remained in solution for the lower flow rate, the $\mathrm{BOD}_{5}$ on COD ratio was significantly improved if compared to the non-treated CTC (Table 1). Indeed, the final CTC concentration was $12 \mathrm{mg} \mathrm{L}^{-1}$, namely below the inhibitory level shown for TC, $18 \mathrm{mg} \mathrm{L}^{-1}$ [24].

Table1

[CTC], COD, and $\mathrm{BOD}_{5} / \mathrm{COD}$ determination after 300 min of CTC electrolysis on a nickel foam electrode.

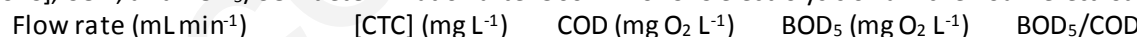

$\begin{array}{lllll}3 & 12 \pm 0.02 & 66 \pm 2 & 18 \pm 3 & 0.27 \pm 0.01\end{array}$

$\begin{array}{lllll}5 & 0 \pm 0.25 & 61 \pm 4 & 20 \pm 3 & 0.33 \pm 0.01\end{array}$

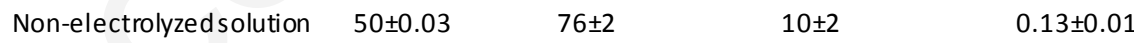

\subsection{Evolution of the generated inorganicions}


Fig. 9. Time-course of the concentrations of $\mathrm{Cl}^{-}, \mathrm{NO}_{3}-$ and $\mathrm{TN}$ during 5 hours of $\mathrm{CTC}$ pre-treatment. Experimental conditions: [CTC $]_{0}=50 \mathrm{mg}$ $\mathrm{L}^{-1}, \mathrm{~T}=298 \mathrm{~K}, \mathrm{E}=0.5 \mathrm{~V} / \mathrm{SCE}, 5 \mathrm{~mL} \mathrm{~min}^{-1}$ flow rate. The inset represents the targeted heteroatoms on the $\mathrm{CTC}$ chemical structure. Error bars are based on duplicate measurements.

According to Fig. 1, chlortetracycline CTC presents three heteroatoms in its chemical structure, 2 nitrogens and 1 chlorine atoms. The removal of the $\mathrm{C}-\mathrm{Cl}$ and $\mathrm{C}-\mathrm{N}$ bonds during the electrolysis was checked. The qualitative and quantitative monitoring of free $\mathrm{Cl}-{ }^{-}, \mathrm{NO}_{2}{ }^{-}$and $\mathrm{NO}_{3}-$ were carried out by ion-exchange chromatography (IC). The oxidation of CTC on nickel foam electrode released free $\mathrm{Cl}-$ and $\mathrm{NO}_{3}-$ in the solution, while nitrite ions were not detected. Fig. 9 shows that the chloride concentration progressively increased during the 5 hours of electrolysis until reaching $7.36 \pm 0.01 \mathrm{mg}$ $\mathrm{L}^{-1}$, corresponding to $99.4 \%$ of the chloride ions expected for a total conversion. The high abundance of $\mathrm{Cl}^{-}$evidenced that CTC underwent a dechlorination process and that chloride ions were not oxidized into chlorine in the conditions of the electrolysis [39]. It is important to note that only few CTC treatment methods lead to its total dechlorination, such as ozonation and thermal decomposition $[18,40]$. Gaseous compounds of nitrogen $\left(\mathrm{NO}_{x}\right.$ and $\left.\mathrm{N}_{2}\right)$ were not released since the total amount of nitrogen TN remained constant $\left(3 \pm 0.1 \mathrm{mg} \mathrm{L}^{-1}\right)$ throughout the electrochemical pretreatment. $2.80 \pm 0.01 \mathrm{mg} \mathrm{L}^{-1}$ of $\mathrm{NO}_{3}{ }^{-}$were accumulated after electrolysis, corresponding to a quasitotal conversion of the nitrogen content. Since the DOC value decreased (Fig. 6b), it can be concluded that the carbon skeleton was also partially degraded and that the main formed by-products contained only carbon and oxygen atoms.

\subsection{Biological treatment}

Fig. 10. Biosorption study of the non-pretreated CTC $\left(50 \mathrm{mg} \mathrm{L}^{-1}\right)$ on activated sludge $\left(0.5 \mathrm{~g} \mathrm{~L}^{-1}\right)$. Error bars are based on duplicate measurements.

Fig. 11. Time-courses of $D O C / D O C_{0}$ during activated sludge culture on chlortetracycline $\left(50 \mathrm{mg} \mathrm{L}^{-1}\right)$ non-electrolyzed, and after oxidation through the percolation cell at a flow rate of $5 \mathrm{~mL} \mathrm{~min}^{-1}$ at $0.5 \mathrm{~V} / \mathrm{SCE}$ in $0.1 \mathrm{~mol} \mathrm{~L}^{-1} \mathrm{NaOH}$. Errorbars are based on duplicate measurements 
The microbial biomass could be an adsorbent of organic compounds [41]. Therefore, possible absorption of CTC on activated sludge was studied. $0.5 \mathrm{~g} \mathrm{~L}^{-1}$ activated sludge was washed in the same conditions as the biological treatment and injected in $100 \mathrm{~mL}$ medium. The flasks were stirred at 250 $\mathrm{rpm}$ at $25^{\circ} \mathrm{C}$. For 2 hours, samples were taken and filtered $(0.45 \mu \mathrm{m}$ pore size $)$ in order to perform DOC measurements. The experiments were duplicated to ensure the reproducibility of the results. As displayed in Fig. 10, DOC removal reached $25 \%$ in the first two hours. CTC adsorption on the bacterial biomass was therefore significant, as previously observed for TC [27, 42]. These results are also in agreement with previous studies, since CTC biosorption on activated sludge have been concluded as a thermodynamically favorable process [43].

Prior to biological treatment, $50 \mathrm{mg} \mathrm{L}^{-1} \mathrm{CTC}$ was electrolyzed in basic medium during $300 \mathrm{~min}$ at 0.5 $\mathrm{V} / \mathrm{SCE}$ with a flow rate of $5 \mathrm{~mL} \mathrm{~min}^{-1}$. After CTC oxidative pre-treatment, a total removal of the target molecule was reached and biodegradability was improved $\left(\mathrm{BOD}_{5} / \mathrm{COD}=0.33\right)$. An activated sludge culture may be then promisingly considered.

Concerning the untreated chlortetracycline, DOC values decreased during the first 2 hours of activated sludge culture, which is in agreement with the previous biosorption study results. As shown in Fig. 11, DOC removal remained constant (around 30\%) until the $9^{\text {th }}$ day and slightly increased from 33 to $42.2 \mathrm{mg} \mathrm{L}^{-1}$ between the $9^{\text {th }}$ and $13^{\text {th }}$ day respectively, most likely due to CTC desorption process. After that, dissolved organic carbon removal remained low and constant (21\%) until the $21^{\text {st }}$ day. These results confirmed that activated sludge culture was ineffective for non-treated CTC mineralization. The decrease of DOC was mainly due to the biosorption of the target molecule on the microorganisms during the first hours of culture. The non-biodegradability of CTC was therefore confirmed.

On the other hand, in the presence of the pre-treated CTC solution, experimental results showed that DOC values decreased during the first 2 days, reaching $18 \%$ of DOC removal. The decrease can be most likely related to the biosorption of the by-products and to the biodegradation of the more readily biodegradable ones [44]. These values remained constant during the next 9 days and then continuously decreased until the $21^{\text {st }}$ day. The period between the $2^{\text {nd }}$ and $9^{\text {th }}$ days corresponded to an acclimatization step of the microorganisms to the residual by-products and the assimilation of intracellular material released by the autolyzed cells [45]. These results fitted with recent research in which a similar period of acclimatization was observed [44]. After that, the DOC removal continuously decreased until the last day of treatment (day 21). It can be concluded that microorganisms activity did not seem to be limited by the presence of inhibitor by-products. Therefore, a longer biological treatment is expected to still improve the mineralization yield. Interestingly, $70 \%$ of mineralization was reached at the end of the biological treatment. From this, the combined process led to $78 \%$ global mineralization efficiency for $50 \mathrm{mg} \mathrm{L}^{-1} \mathrm{CTC}$ solution, with $28 \%$ corresponded to the oxidative pretreatment and $70 \%$ of the remaining by-products to the biological treatment.

\section{- Conclusions}


Since the non-biodegradability of CTC was confirmed with a value of 0.13 as an initial $\mathrm{BOD}_{5} / \mathrm{COD}$ ratio, a combined process involving an electrochemical pre-treatment, expected to improve biodegradability, prior to biological treatment was highly recommended. The feasibility of CTC oxidation on nickel foam electrode was confirmed. In alkaline medium, an electrochemical oxidation on nickel foam electrode was concluded to be an efficient method for chlortetracycline pretreatment. The oxidation yield exceeded $99 \%$ for a $50 \mathrm{mg} \mathrm{L}^{-1}$ initial CTC concentration, $0.5 \mathrm{~V} / \mathrm{SCE}$ potential and $5 \mathrm{~mL} \mathrm{~min}{ }^{-1}$ flow rate. Interestingly, the mild conditions used for electrooxidation did not lead to the formation of chlorine and so to toxic chlorinated by-products. Total dechlorination and denitrogenation were achieved making the solution less toxic for the microorganisms. Indeed, the $\mathrm{BOD}_{5}$ on $\mathrm{COD}$ ratio was significantly improved for only $27 \%$ of DOC removal. A subsequent biological treatment became then relevant; it led to $70 \%$ of mineralization after 21 days of activated sludge culture. Consequently, the combined process led to $78 \%$ global mineralization efficiency for $50 \mathrm{mg} \mathrm{L}^{-1} \mathrm{CTC}$ solution. 


\section{References}

[1] B. Albero, J.L Tadeo, M. Escario, E. Miguel, R.A. Pérez, Persistence and availability of veterinary antibiotics in soil and soil-manure systems, Sci. Total Environ. 643 (2018) 1562-1570. https://doi.org/10.1016/j.scitotenv.2018.06.314

[2] L. Wang, G.-G. Ying, J.-L. Zhao, X.-B. Yang, F. Chen, R. Tao, S. Liu, L.-J. Zhou, Occurrence and risk assessment of acidic pharmaceuticals in the Yellow River, Hai River and Liao River of north China, Sci. Total Environ. 408 (2010) 3139-3147. https://doi.org/10.1016/j.scitotenv.2010.04.047

[3] C. for D.E. and Research, Novel Drug Approvals for 2016, FDA. (2020). http://www.fda.gov/drugs/new-drugs-fda-cders-new-molecular-entities-and-new-therapeuticbiological-products/novel-drug-approvals-2016

[4] R. Daghrir, P. Drogui, Tetracycline antibiotics in the environment: a review, Environ. Chem. Lett. 11 (2013) 209-227. https://doi.org/10.1007/s10311-013-0404-8.

[5] C.-X. Liu, Q.-M. Xu, S.-C. Yu, J.-S. Cheng, Y.-J. Yuan, Bio-removal of tetracycline antibiotics under the consortium with probiotics Bacillus clausii $\mathrm{T}$ and Bacillus amyloliquefaciens producing $\begin{array}{llllll}\text { biosurfactants, } & \text { Sci. } & \text { Total } & \text { Environ. } & 710 & \text { (2020) }\end{array}$ https://doi.org/10.1016/j.scitotenv.2019.136329

[6] K. Kümmerer, Pharmaceuticals in the Environment, Annu. Rev. Env. Resour. 35 (2010) 57-75. https://doi.org/10.1146/annurev-environ-052809-161223.

[7] T. Han, Y. Liang, Z. Wu, L. Zhang, Z. Liu, Q. Li, X. Chen, W. Guo, L. Jiang, F. Pan, S. Ge, Z. Mi, Z. Liu, H. Huang, X. Li, J. Zhou, Y. Li, J. Wang, Z. Zhang, Y. Tang, L. Yang, M. Wu, Effects of tetracycline on growth, oxidative stress response, and metabolite pattern of ryegrass, J. Hazard. Mater. 380 (2019) 120885. https://doi.org/10.1016/j.jhazmat.2019.120885.

[8] Joumal officiel de I'Union européenne. https://eur-lex.europa.eu/legalcontent/FR/TXT/HTML/?uri=OJ:JOL_2015_078_R_0008 HYPERLINK "https://eurlex.europa.eu/legal-content/FR/TXT/HTML/?uri=OJ:JOL_2015_078_R_0008\&from=FR"\& HYPERLINK "https://eur-lex.europa.eu/legalcontent/FR/TXT/HTML/?uri=OJ:JOL_2015_078_R_0008\&from=FR"from=FR (accessed 27 July 2020).

[9] L. Tong, S. Huang, Y. Wang, H. Lu, M. Li, Occurrence of antibiotics in the aquatic environment of Jianghan Plain, central China, Sci. Total Environ. 497-498 (2014) 180-187. https://doi.org/10.1016/i.scitotenv.2014.07.068

[10] B. Liu, Y. Li, X. Zhang, J. Wang, M. Gao, Effects of chlortetracycline on soil microbial communities: Comparisons of enzyme activities to the functional diversity via Biolog EcoPlates ${ }^{\mathrm{TM}}$, Eur. J. Soil Biol. 68 (2015) 69-76. https://doi.org/10.1016/i.ejsobi.2015.01.002 
[11] R.X. Guo, J.Q. Chen, Phytoplankton toxicity of the antibiotic chlortetracydine and its UV light $\begin{array}{lllll}\text { degradation } \quad \text { products, } & \text { Chemosphere } & 87 & \text { (2012) } & 1254-1259 .\end{array}$ https://doi.org/10.1016/j.chemosphere.2012.01.031

[12] S.C. Anderson, S. Subbiah, A. Gentles, D. Oliver, P. Stonum, T.A. Brooks, E.E. Smith, Qualitative and quantitative drug residue analyses: Chlortetracycline in white-tailed deer (Odocoileus virginianus) and supermarket meat by liquid chromatography tandem-mass spectrometry, J. Chromatogr. B. 1092 (2018) 237-243. https://doi.org/10.1016/j.jchromb.2018.05.027

[13] X. Liao, R. Zou, B. Li, T. Tong, S. Xie, B. Yuan, Biodegradation of chlortetracycline by acclimated $\begin{array}{llllll}\text { microbiota, Process Saf. Environ. Prot. } 109 & \text { (2017) 11-17. }\end{array}$ https://doi.org/10.1016/j.psep.2017.03.015

[14] J.-M. Fontmorin, F. Fourcade, F. Geneste, I. Soutrel, D. Floner, A. Amrane, Direct electrochemical oxidation of a pesticide, 2,4-dichlorophenoxyacetic acid, at the surface of a graphite felt electrode: Biodegradability improvement, C. R. Chim. 18 (2015) 32-38. https://doi.org/10.1016/j.crci.2014.05.004

[15] A. Alahabadi, A. Hosseini-Bandegharaei, G. Moussavi, B. Amin, A. Rastegar, H. Karimi-Sani, M. Fattahi, M. Miri, Comparing adsorption properties of $\mathrm{NH} 4 \mathrm{Cl}$-modified activated carbon towards chlortetracycline antibiotic with those of commercial activated carbon, J. Mol. Liq. 232 (2017) 367-381. https://doi.org/10.1016/j.molliq.2017.02.077

[16] Y. Yue, C. Shen, Y. Ge, Biochar accelerates the removal of tetracyclines and their intermediate s by altering soil properties, J. Hazard. Mater. $380 \quad$ (2019) 120821. https://doi.org/10.1016/j.jhazmat.2019.120821

[17] Q. Xu, Q. Zhou, M. Pan, L. Dai, Interaction between chlortetracycline and calcium-rich biochar: Enhanced removal by adsorption coupled with flocculation, Chem. Eng. J. 382 (2020) 122705. https://doi.org/10.1016/j.cej.2019.122705.

[18] M.H. Khan, J.-Y. Jung, Ozonation of chlortetracydine in the aqueous phase: Degradation intermediates and pathway confirmed by NMR, Chemosphere 152 (2016) 31-38. https://doi.org/10.1016/j.chemosphere.2016.01.063

[19] R. Daghrir, P. Drogui, N. Delegan, M.A. El Khakani, Removal of chlortetracycline from spiked municipal wastewater using a photoelectrocatalytic process operated under sunlight irradiations, Sci. Total Environ. 466-467 (2014) 300-305. https://doi.org/10.1016/j.scitotenv.2013.07.001

[20] D. Kanakaraju, B.D. Glass, M. Oelgemöller, Advanced oxidation process-mediated removal of pharmaceuticals from water: A review, J. Environ. Manage. 219 (2018) 189-207. https://doi.org/10.1016/j.jenvman.2018.04.103

[21] F. Zaviska, P. Drogui, J.-F. Blais, G. Mercier, S. De La Rochebrochard d'Auzay, Electrochemical Oxidation of Chlortetracydine Using $\mathrm{Ti} / \mathrm{IrO} 2$ and $\mathrm{Ti} / \mathrm{PbO} 2$ Anode Electrodes: Application of Experimental Design Methodology, J. Environ. Eng. 139 (2013) 810-821. https://doi.org/10.1061/(ASCE)EE.1943-7870.0000686 
[22] S. Qian, S. Liu, Z. Jiang, D. Deng, B. Tang, J. Zhang, Electrochemical Degradation of Tetracycline Antibiotics Using a Ti/SnO2-Sb2O3/PbO2 Anode: Kinetics, Pathways, and Biotoxicity Change, J. Electrochem. Soc. 166 (2019) E192. https://doi.org/10.1149/2.1411906jes

[23] D. Mansour, F. Fourcade, I. Soutrel, D. Hauchard, N. Bellakhal, A. Amrane, Relevance of a combined process coupling electro-Fenton and biological treatment for the remediation of sulfamethazine solutions - Application to an industrial pharmaceutical effluent, C. R. Chim. 18 (2015) 39-44. https://doi.org/10.1016/j.crci.2014.05.005

[24] S. Yahiat, F. Fourcade, S. Brosillon, A. Amrane, Removal of antibiotics by an integrated process coupling photocatalysis and biological treatment - Case of tetracycline and tylosin, Int. Biodeterior. Biodegrad.65(2011) 997-1003. https://doi.org/10.1016/j.ibiod.2011.07.009

[25] F. Geneste, Catalytic electrochemical pre-treatment for the degradation of persistent organic $\begin{array}{llllll}\text { pollutants, } & \text { Curr. } & \text { Opin. } & \text { Electrochem. } & 11 & \text { (2018) }\end{array}$ https://doi.org/10.1016/j.coelec.2018.07.002

[26] D. Belkheiri, F. Fourcade, F. Geneste, D. Floner, H. Aït-Amar, A. Amrane, Feasibility of an electrochemical pre-treatment prior to a biological treatment for tetracycline removal, Sep. Purif. Technol. 83 (2011) 151-156. https://doi.org/10.1016/j.seppur.2011.09.029

[27] D. Belkheiri, F. Fourcade, F. Geneste, D. Floner, H. Aït-Amar, A. Amrane, Combined process for removal of tetracycline antibiotic - Coupling pre-treatment with a nickel-modified graphite felt electrode and a biological treatment, Int. Biodeterior. Biodegrad. 103 (2015) 147-153. https://doi.org/10.1016/j.ibiod.2015.02.032

[28] R.M. Farinos, R.L. Zornitta, L.A.M. Ruotolo, R.M. Farinos, R.L. Zornitta, L.A.M. Ruotolo, Development of Three-Dimensional Electrodes of PbO2 Electrodeposited on Reticulated Vitreous Carbon for Organic Eletrooxidation, J. Braz. Chem. Soc. 28 (2017) 187-196. https://doi.org/10.5935/0103-5053.20160162

[29] S. Langlois, F. Coeuret, Flow-through and flow-by porous electrodes of nickel foam. II. Diffusionconvective mass transfer between the electrolyte and the foam, J. Appl. Electrochem. 19 (1989) 51-60. https://doi.org/10.1007/BF01039389

[30] L. Feng, Y. Zhu, H. Ding, C. Ni, Recent progress in nickel based materials for high performance pseudocapacitor electrodes, J. Power Sources. 267 (2014) 430-444. https://doi.org/10.1016/j.jpowsour.2014.05.092

[31] Z. Zhang, J. Li, C. Luan, H. Wang, X. Cheng, L. Fang, L. Wang, B. Zhao, C. Ma, H. Zhang, C. Li, J. Xu, Preparation and characterization of palladium/polypyrrole-reduced graphene oxide/foamed nickel composite electrode and its electrochemical dechlorination of triclosan, Arab. J. Chem. 13 (2020) 3963-3973. https://doi.org/10.1016/i.arabjc.2019.04.006

[32] J.-M. Fontmorin, S. Huguet, F. Fourcade, F. Geneste, D. Floner, A. Amrane, Electrochemical oxidation of 2,4-Dichlorophenoxyacetic acid: Analysis of by-products and improvement of the biodegradability, Chem. Eng. J. 195-196 (2012) 208-217. https://doi.org/10.1016/i.cej.2012.04.058 
[33] C. Moinet, Electrosynthèse organique en continu. Méthodes directes et indirectes, J. Phys. IV France. 04 (1994) C1-175-C1-184. https://doi.org/10.1051/jp4:1994113

[34] J.-M. Fontmorin, F. Fourcade, F. Geneste, D. Floner, S. Huguet, A. Amrane, Combined process for 2,4-Dichlorophenoxyacetic acid treatment-Coupling of an electrochemical system with a biological treatment, Biochem. Eng. J. 70 (2013) 17-22. https://doi.org/10.1016/j.bej.2012.09.015

[35] E. Asgari, A. Esrafili, R. Rostami, M. Farzadkia, $\mathrm{O}_{3}, \mathrm{O}_{3} / \mathrm{UV}$ and $\mathrm{O}_{3} / \mathrm{UV} / \mathrm{ZnO}$ for abatement of parabens in aqueous solutions: Effect of operational parameters and mineralization/biodegradability improvement, Process Saf. Environ. Prot. 125 (2019) 238-250. https://doi.org/10.1016/j.psep.2019.03.032

[36] E. Aydın, M. Şahin, E. Taşkan, H. Hasar, M. Erdem, Chlortetracycline removal by using hydrogen based membrane biofilm reactor, J. Hazard. Mater. 320 (2016) 88-95. https://doi.org/10.1016/j.jhazmat.2016.08.014

[37] F.C. Moreira, R.A.R. Boaventura, E. Brillas, V.J.P. Vilar, Electrochemical advanced oxidation processes: A review on their application to synthetic and real wastewaters, Appl. Catal. B: Environ. 202 (2017) 217-261. https://doi.org/10.1016/j.apcatb.2016.08.037

[38] V. Sarria, S. Parra, N. Adler, P. Péringer, N. Benitez, C. Pulgarin, Recent developments in the coupling of photoassisted and aerobic biological processes for the treatment of biorecalcitrant compounds, Catal. Today. 76 (2002) 301-315. https://doi.org/10.1016/S0920-5861(02)00228-6.

[39] A. Shoiful, Y. Ueda, R. Nugroho, K. Honda, Degradation of organochlorine pesticides (OCPs) in water by iron (Fe)-based materials, J. Water Process Eng. 11 (2016) 110-117. https://doi.org/10.1016/i.jwpe.2016.02.011

[40] P. Cervini, L.C.M. Machado, A.P.G. Ferreira, B. Ambrozini, ÿder T.G. Cavalheiro, Thermal decomposition of tetracycline and chlortetracycline, J. Anal. Appl. Pyrolysis. 118 (2016) 317-324. https://doi.org/10.1016/j.jaap.2016.02.015

[41] N.B. Singh, G. Nagpal, S. Agrawal, Rachna, Water purification by using Adsorbents: A Review, Environ. Technol.Inno. 11 (2018) 187-240. https://doi.org/10.1016/j.eti.2018.05.006

[42] R. Pulicharla, R.K. Das, S.K. Brar, P. Drogui, S.J. Sarma, M. Verma, R.Y. Surampalli, J.R. Valero, Toxicity of chlortetracycline and its metal complexes to model microorganisms in wastewater sludge, Sci. Total Environ. 532 (2015) 669-675. https://doi.org/10.1016/j.scitotenv.2015.05.140

[43] H. Li, Y. Wang, W. Ben, Z. Qiang, Adsorption behavior of chlortetracycline on activated sludge, Chinese J. Environ. Eng. 7 (2013) 4729-4734.

[44] I. Yahiaoui, L. Yahia Cherif, K. Madi, F. Aissani-Benissad, F. Fourcade, A. Amrane, The feasibility of combining an electrochemical treatment on a carbon felt electrode and a biological treatment for the degradation of tetracycline and tylosin - application of the experimental design methodology, Sep. Sci. Technol. 53 (2018) 337-348. https://doi.org/10.1080/01496395.2017.1385626 
[45] N.A. Salles, F. Fourcade, F. Geneste, D. Floner, A. Amrane, Relevance of an electrochemical process prior to a biological treatment for the removal of an organophosphorous pesticide, phosmet, J. Hazard. Mater. 181 (2010) 617-623. https://doi.org/10.1016/j.jhazmat.2010.05.057 